\title{
Particulate Matter: An Approach To Air Pollution
}

\author{
Francis Olawale Abulude \\ Science and Education Development Institute, Akure, Ondo State, Nigeria; \\ waleabul@yahoo.com
}

\begin{abstract}
Particulate matter (PM) is one of the problems faced in environmental science. It has health effects on man and animals in both developed and developing countries. Research and efforts have been on it several years back. Policy statements and efforts have been published. This review paper is an added information on air pollution. In it, efforts were made in discussing these: classification, effects, methodology, case studies and source apportionment. It is hoped that this paper would contribute to existing knowledge on PM.
\end{abstract}

Keywords: PM, pollution, environment, industrialization, health effects, standards.

\section{Introduction}

Air pollution has been of major concern throughout the world due to the health effects on human, animal and materials. This issue is receiving much attention, due to the fact that both in developed and developing countries there has been an increase in urbanization due to higher activities in transportation and industrialization (Abiye et al., 2013). The growing concerns about the health implications of air, water, and soil pollution to ecosystem have led to the establishment of agencies which are saddled with the responsibility of combating the adverse effects (Ezeh et al., 2014). Examples of these organization, agencies and departments are World Health Organisation (WHO), United State Environmental Protection Agency (USEPA), United Nations (UN), and Central Pollution Control Board (CPCB) from India. The local, national and international agencies are working and concentrating on pollutions in the environment and publishing and issuing documents to improve the air quality. (Department of Environmental, Food and Rural Affairs (2015).

The aim of this paper was to give a proper insight on particulate matter. To do this, the following objectives were considered, classification, effects, methodology, case studies and source apportionment.

\section{Atmospheric Deposition}

According to Amodio et al. (2014), atmospheric deposition has been defined as the transfer of pollutants to terrestrial and aquatic ecosystems. They further classified the deposition as dust, particulate matter (PM) containing heavy metals, polycyclic aromatic hydrocarbons, dioxin, furans, sulphates, nitrates. Table 1 depicts the mechanisms of pollution depositions. In this table, it is noted that deposition occurs in three ways: wet, dry and bulk (total).

Table 1: Mechanisms of deposition

\begin{tabular}{lcc}
\hline Deposition & Rain Washout \\
Wet deposition & \multicolumn{1}{c}{ No Precipition only during rain) } & \\
Dry deposition & Below a cloud \\
Bulk deposition & Wet and dry deposition & \\
& Collected together & \\
\hline
\end{tabular}

Source: Amodio et al., 2014 
In this review paper, an effort would be geared towards, one of the atmospheric pollutants PM. The cause, health implication, sampling procedures, analytical methods and sources of emission would be highlighted.

Classification of PM

\section{PARTICULATE MATTER}

1. Total suspended Particulates (TSP, with aerodynamic diameter $<30$ microns $(\mu \mathrm{m})$

2. $\quad \mathrm{PM}_{10}$ (with an aerodynamic diameter of less than $10 \mu \mathrm{m}$ (coarse)

3. PM 2.5 (with an aerodynamic diameter of less than $2.5 \mu \mathrm{m}$ (fire)

4. Ultrafine PM is that diameter of less than 0.1 microns (Fig 1).

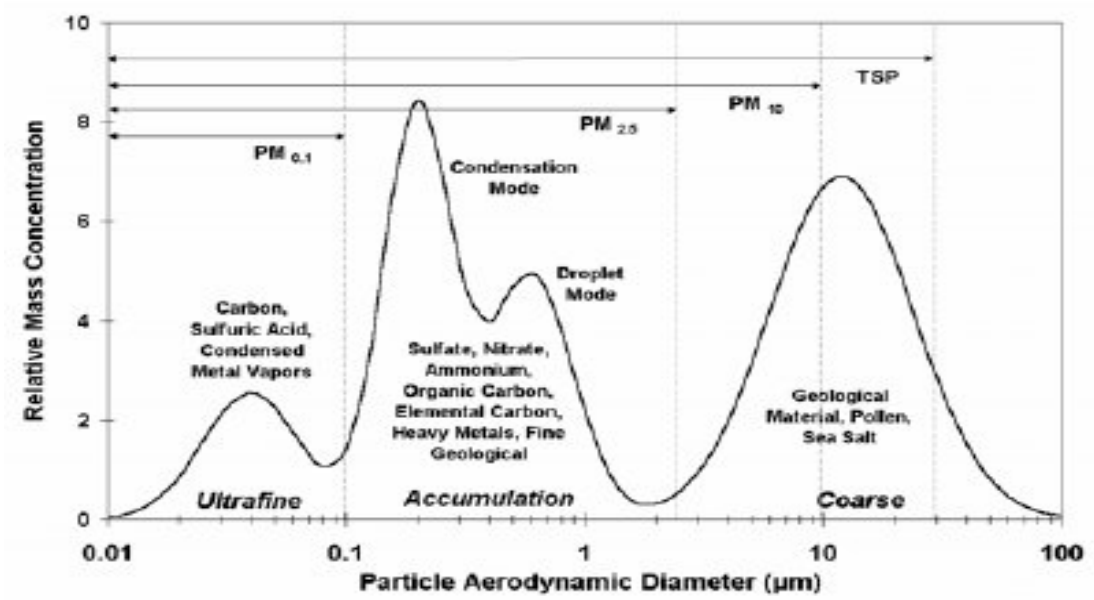

Fig 1: Particle Size Distribution. Source: Johnson et al. (2011)

Furthermore, PM can be classified as primary particles which are emitted into the atmosphere through industrial activities, road traffic, road dust, sea spray, and windblown soil, they also contain carbon and an organic compound, metals and metal oxides and ions. Secondary particles are formed through chemical transformation of gaseous. Examples: $\mathrm{SO}_{2}-$ Sulphates, $\mathrm{NO}_{x}-$ Nitrates, $\mathrm{NH}_{3}-\mathrm{Ammonium}$ ions, VOC's - Secondary Organic Aerosol (Johnson et al., 2011).

PM is known to be the major contributor to the adverse health effects of the air pollution. Several studies have been carried out on this subject matter. Alahmr et al. (2012) studied air pollution as a dust falls around semi-urban areas in Malaysia, Ikamaise et al. (2013) worked on total suspended particulate matter in Calabar air basin. In the case of Change et al. (2013), they worked on PM2.5 in Guangzhou, Co et al. (2014) had their study on ambient particulate matter of a mountainous site, Moses and Orok (2015) studied suspended particulate matter in Uyo, Nigeria, while Ezeh et al. (2012) concluded their study on $\mathrm{PM}_{10}$ and PM2.5 samples obtained in Ikoyi, Lagos, Nigeria. In all these case studies, it was confirmed that the emitted PM are released directly from secondary processes.

\section{Effects of PM}

PM has been confirmed to have health implications on the human. Onabowale and Owoade (2015), stated that about $28 \%$ of the sickness and death is caused by indoor air particulate in developing countries. This was collaborated by the results of the studies carried out by WHO (2014). WHO (2014), attributed more than 7 million death to the impact of PM (indoor and outdoor). In India, (Delhi) air pollution has been reported to cause between 10,000 to 30,000 deaths every year (Gopalaswami, 2016), acute and chronic problems are due to inhalation of PM10 and PM2.5 (Ezeh et al., 2012), and damage to respirative organs (Moses and Orok, 2015)

Ontario Ministry of the Environmental and Climate Change (2010), reported that the greatest effect on health is from PM2.5. This has resulted in hospitalization. Affected people (Old and Children) with asthma, cardiovascular and lung diseases are most vulnerable to fine PM. Duration of exposure has an effect on the sickness. According to the Economic Times Quoted by Gopalaswami (2016), it was noted 
that over $85 \%$ of the world's population lives in an area tagged by World Health Organization to be unsafe. The air pollution there is above the safe level. This showed that more than 5.5million people die prematurely due to the effect of pollution. The findings concluded that out of this deaths, half was from China and India. In a related development, Chang et al. (2013) and Obioh et al. (2013) attributed the role of fine PM on poor visibility, corrosion, damage to vegetation and soiling. Apart from the damage done to materials, PM also disturbs the atmospheric chemistry and the radiation balance by scattering and absorbing solar radiation and also alter the formation of cloud droplets.

\section{Sources of PM}

It is worthy of note that many types of research are based on $\mathrm{PM}_{10}, \mathrm{PM}_{2.5}$, and sub-micron PM, while some are still based on total suspended particulates (TSP). Particulate pollution varies widely across countries in composition, distribution and sources. The assessment of PM concentrations and sources depend largely on the local sources within urban areas and long-range transport of the air pollutants. The PM sources in developing countries are much wider than those from developed (Industrial country). This is because of the increase and fast transition between rural and urban economies.

Sources of PM in the urban and rural are different, while in rural cooking with solid fuels is rampant so also biomass burning, but in the urban, it is fossil fuel. In the reviewed of Johnson et al. (2011), it was noted that major sources of pollution in urban places are heating and household cooking, using traditional fuels, animal husbandry, industrial processes, burning of fossil fuels. In developing countries most especially Africa, Latin America and Asia, oil, biomass and coal are the main source of pollution. Both in industrial and developing countries of the world, a major source of PM has been motor vehicles, this is due to the fuel used in powering them like diesel. In fact in developing countries, due to economic hardship most vehicles used are old, they do not meet clean emission standards. As a result, they tend to be more polluting.

According to literature cited, it was observed that the most contributors to PM include vehicles, industrial activity, household fuel, power sector, fugitive dust and unprocessed biomass fuel like wood, dung and crop residues (Alahmr et al. (2012), Dallman et al. (2014), Crilley et al. (2004), Onabowale and Owoade (2015), Fawole et al. (2016), Owoade et al. (2015) and Orogade et al. (2016). Dust storms, smoke from forests and grass fires, volcanic activities and spring dust have been noted to raise the PM levels above WHO guidelines.

In conclusion, anthropogenic and non-anthropogenic activities are the causes of elevated PM in the atmosphere. No doubt PM has affected the air quality management program.

\section{Air Quality Index}

The Air Quality Index (AQI) is a pointer that determines the degree of pollution in an area or monitoring location by calculation. The pollutants determined are particulate matter, ground-level ozone, sulfur dioxide, carbon monoxide and nitrogen dioxide. Each of these pollutants have an air quality standard which is used to calculate the overall AQI for the city (AirNow, 2016). AQI is used to assist someone in understanding what local air quality means to one's health (Fig 2). 


\begin{tabular}{|l|l|l|} 
& \\
& \\
\hline $\begin{array}{l}\text { Air Quality Index } \\
\text { (AQI) Values }\end{array}$ & $\begin{array}{l}\text { Levels of } \\
\text { Health Concern }\end{array}$ & Colors \\
\hline When the AQl is in & ...air quality & ...assymbolized \\
\hline this range: & conditions are: & bythis color: \\
\hline 51 to 50 & Good & Green \\
\hline 101 to 150 & Moderate & Yellow \\
\hline 151 to 200 & Sensitive Groups & Orange \\
\hline 201 to 300 & Unhealthy & Red \\
\hline
\end{tabular}

a. General Quality Index for the Pollutants

\begin{tabular}{|c|c|}
\hline AQIValue & $\begin{array}{l}\text { Actions To Protect Your Health } \\
\text { From Particle Pollution }\end{array}$ \\
\hline $\begin{array}{l}\text { Good } \\
(0-50)\end{array}$ & None \\
\hline $\begin{array}{l}\text { Moderate } \\
\left(51-100^{*}\right)\end{array}$ & $\begin{array}{l}\text { Unusually sensitive people should } \\
\text { consider reducing prolonged or heavy } \\
\text { exertion. }\end{array}$ \\
\hline $\begin{array}{l}\text { Unhealthy } \\
\text { for Sensitive } \\
\text { Groups } \\
(101-150)\end{array}$ & $\begin{array}{l}\text { The following groups should reduce } \\
\text { prolonged or heavy exertion: } \\
\text { - People with heart or lung disease } \\
\text { - Children and older adults }\end{array}$ \\
\hline $\begin{array}{l}\text { Unhealthy } \\
\text { (151-200) }\end{array}$ & $\begin{array}{l}\text { The following groups should avoid } \\
\text { prolonged or heavy exertion: } \\
\text { - People with heart or lung disease } \\
\text { - Children and older adults } \\
\text { Everyone else should reduce } \\
\text { prolonged or heavy exertion. }\end{array}$ \\
\hline $\begin{array}{l}\text { Very Unhealthy } \\
\text { (201-300) }\end{array}$ & $\begin{array}{l}\text { The following groups should avoid all } \\
\text { physical activity outdoors: } \\
\text { - People with heart or lung disease } \\
\text { - Children and older adults } \\
\text { Everyone else should avoid prolonged } \\
\text { or heavy exertion. }\end{array}$ \\
\hline \multicolumn{2}{|c|}{$\begin{array}{l}\text { For particles up to } 2.5 \text { micrometers in diameter: An AQl of } 100 \text { corresponds } \\
\text { to } 35 \text { mikrograms per cubic meter (averaged over } 24 \text { hours). }\end{array}$} \\
\hline $\begin{array}{l}\text { For particles up to } \\
\text { to } 150 \text { micrograms }\end{array}$ & $\begin{array}{l}\text { ometers in dlameter: An AQI of } 100 \text { corresponds } \\
\text { bic meter (averaged over } 24 \text { hours). }\end{array}$ \\
\hline
\end{tabular}

b. PM Quality Index Chart

Fig 2: Air Quality Index. Source: AirNow (2016).

AQI is represented numbers - 0 to 500 with 0 representing good air and 500 representing hazardous air. The AQI is broken down into six categories, each color coded with the number scale.

- Good (green) is for numbers 0 through 50 and means satisfactory air quality

- Moderate (yellow) is 51-100 and is for acceptable air quality

- Unhealthy for Sensitive Groups (tan) is 101-150 and means sensitive individuals with sensitive skin may be affected

- Unhealthy (red) is 151-200 and almost everyone may experience problems.

o Very unhealthy (pink) 210-300 is a health alert, where everyone may have health problems

- Hazardous (purple) over 300 numbers may contribute to emergency health problems and will affect most people (AirNow, 2016).

\section{Calculation of Index}

An index for any given pollutant is its concentration expressed as a percentage of the relevant standard, or:

$$
\text { Index }=\underline{\text { Pollutant Concentration }} \times 100
$$

Where:

$100=$ The pollutant is currently at a concentration equal to an environmental standard level. 
Pollutant Standard Level $=50 \mu \mathrm{g} / \mathrm{m} 324$ hours of PM10 readings

$80 \mu \mathrm{g} / \mathrm{m} 3$ hourly average PM10 reading

\section{Regulatory Standards and Events}

The international, national and local communities are aware of the implications of PM to man, animal and materials to this fact, efforts have been geared up to reduce the sources of this air pollution. WHO, UNICEF, and other international bodies have put in efforts even more to the cause of reduction to PM into the atmosphere. Safety limits have been formulated to act as standards for the threshold. In the same effort, national and local governments have put in place research centers and regulatory bodies to oversee, research and to set emission standards.

In 2011, there was a severe haze event in Beijing due to high PM level (between $71.9102 .2 \mu \mathrm{g} / \mathrm{m}^{3}$ ) this caused poor visibility and adverse effect on human health (Lang et al., 2012; Yuan et al., 2012). To this effect, Ambient Air Quality Standard (NAAQS) was proposed in China in the beginning of 2012 for the first time.

Copalaswami (2016), reported that in 2014 WHO declared Delhi to be the worst polluted city in the world due to the elevated level of PM. It was recorded as PM2.5 $\left(295 \mu \mathrm{g} / \mathrm{m}^{3}\right)$ and PM10 $\left(470 \mu \mathrm{g} / \mathrm{m}^{3}\right)$ which are far above Air Quality limit of $430-435 \mu \mathrm{g} / \mathrm{m}^{3}$ ). The safety standard is prescribed by Central Pollution Control Board (CPCB) of India.

In 1988, there was an event where toxic wastes were reportedly dumped in a village called Koko in the eastern part of Nigeria. To avoid the repeated dumping, Federal Environmental Protection Agency was established, it was saddled with the monitoring and regulation of environmental pollution in the country. Now, FEPA has transformed into The National Environmental Standards and Regulations Enforcement Agency (NESREA) saddled with enforcing all environmental laws, guidelines, policies, standards and regulations in Nigeria, as well as enforcing compliance with provisions of international agreements, protocols, conventions and treaties on the environment to which Nigeria is a signatory (NESREA, 2016).

In one of the studies at receptor sites in Lagos, Nigeria the PM levels were reported higher than the 150 $\mu \mathrm{g} / \mathrm{m}^{3}$ set by NAAQS. The authors reported between 150 and $240 \mu \mathrm{g} / \mathrm{m}^{3}$ for PM 2.5 and $370-600 \mu \mathrm{g} / \mathrm{m}^{3}$ for PM10 (Owoade et al., 2013). Minka and Ayo (2014) documented that in harmattan period at the northern part of Nigeria, $400-1200 \mathrm{~kg} / \mathrm{ha}$ dust particles were deposited as compared to $100-400 \mathrm{~kg} / \mathrm{ha}$ in the Southern part. According to Taiwo et al. (2015) most of the PM results collected (TSP, 1033-40,000 PM10 $\mu \mathrm{g} / \mathrm{m}^{3}$ ) and also PM10 ranged between 118.3-132.0 $\mu \mathrm{g} / \mathrm{m}^{3}$ ) in Nigeria were far above recommended values (USEPA, $40 \mu \mathrm{g} / \mathrm{m}^{3}$ ) for PM10 and (WHO, $90 \mu \mathrm{g} / \mathrm{m}^{3}$ for TSP).

Recently, there has been signs of improvements in some megacities of developed countries with relationship to PM this is due to the implementation of Urban Air Quality Management plan (UAQMP) (Gulia et al., 2015). According to European Environmental Agency (EEA, 2014) report, between 1990 and 2009 pollutants have reduced to 16\% (PM10) and 21\% (PM2.5). Despite concerted efforts, it has also been pointed out that 18 to $49 \%$ of the population in these countries are still endangered to exposure to PM10 values exceeding the standards limits (EEA, 2014). In the US mega cities the high values for PM concentration obtained in 1999 had by 2010 reduced by about 38\%, but in some areas, the safety limits are being violated (USEPA, 2012). However, the average trend of PM2.5 has remained less constant or more from 1997 to 2009 (Gulia et al., 2015).

In Singapore, Japan, and Hong Kong the people are facing serious PM problem due to an increase in motorized transport (Edesess, 2011).

\section{Relationship of PM with Meteorological factors}

Wind speed and direction have been termed the fundamental parameters in the movement of air contaminants. All these are inter linked to temperature. In other words, the greater the wind speed, the greater the turbulence and the more rapid and complete the dispersion of contaminants in the air (Guttikunda and Gurjar, 2012). 
Based on the study of Guttikunda and Gurjar (2012) using models it was observed that there was a relationship between the two. The higher wind speeds were responsible for driving part of the pollution out of the city limits. Sarasamma and Narayanan (2014) revealed the micrometeorological parameters such as wind speed, wind direction, temperature, atmospheric pressure and relative humidity have a great effect on the movement of PM as well as the concentration level at any particular area. Langner et al. (2011) in their book, wrote that deposition rates are governed by meteorological factors (wind velocity, relative humidity), particle characteristics (size and shape), and surface characteristics (friction velocity, microscale roughness, and temperature).

Meteorological parameters which cause the dilution of pollutants rates of chemical reactions and the removal processes such as dry and wet deposition are important factors affecting the particle concentration in the ambient air (Johnson et al., 2014)

\section{Sampling and Analytical Techniques}

The choice of suitable analytical method for atmospheric deposition depends on the parameter of choice. For analysis of atmosphere deposition, Amodio et al. (2014) divided the procedure into three parts namely, dry, wet and occult (Bulk) depositions. They listed different collectors for organic pollutants, inorganic, mercury, biodeposition, and particulate matter. The sampling and analytical techniques interested in this review is PM.

\section{Sample Collectors (Samplers)}

Table 2 depicts the sample collectors reviewed in this paper. All the sample collectors are placed on a stand at about $1.5-2 \mathrm{~m}$ high above the ground. This is just to avoid splashing of rain or water into the sample collector (To avoid contamination). The simple collector used in each study (1-5) are just an HDPE. Funnel and container to retain water and PM. The funnel is fitted into the mouth of the container and the container placed on the stand and fixed on it.

It is possible to collect dry and wet depositions separately using the samples equipped with two polyethylene buckets and a lid controlled by a rain sensor, which moves depending on the beginning and the end of the rain event.

Typical sampling periods, in fact, vary from one week to one month, depending on meteorological condition. After the deposition collection, the sample is transferred to the laboratory in the sampling bottle (wet only and bulk) or bucket (Bargerhoff), filtered and analyzed. 
Table 2: List of Samplers Used in Sample Collection

\begin{tabular}{|c|c|c|c|c|}
\hline Sampler & Study & Location & Collection Periods & References \\
\hline $\begin{array}{l}\text { 1. Funnel - Open } \\
\text { Polyethylene } \\
\text { Cylinder }\end{array}$ & $\begin{array}{l}\text { Atmospheric Bulk } \\
\text { deposition (TAD) }\end{array}$ & Belgrade & $\begin{array}{l}\text { June } 2002 \text { - Dec. } 2006 \\
\text { (monthly) }\end{array}$ & Tasic et al. (2009) \\
\hline $\begin{array}{l}\text { 2. Collecting Glass } \\
\text { Bottles }\end{array}$ & PM Deposition & $\begin{array}{l}\text { Port of Koper } \\
\text { Slovenia }\end{array}$ & Oct. 2005 - Oct. 2006 & Jereb et al. (2009) \\
\hline $\begin{array}{l}\text { 3. HDPE Funnel } \\
\text { Connected to a } \\
\text { polyethylene bottle }\end{array}$ & $\begin{array}{l}\text { Total Atmospheric } \\
\text { Deposition }\end{array}$ & Cedex, France & $\begin{array}{l}\text { Nov. } 1999 \text { - April } 2000 \\
\text { May } 2000 \text { - July } 2000 \\
\text { (monthly) }\end{array}$ & Azimi et al. (2003) \\
\hline $\begin{array}{l}\text { 4. Polyethylene bottles } \\
\text { Equipped with a funnel }\end{array}$ & Dust Fall & $\begin{array}{l}\text { Selangor, } \\
\text { Malaysia }\end{array}$ & July - October 2010 & Alahmr et al. (2012) \\
\hline \multicolumn{5}{|l|}{$\begin{array}{l}\text { 5. HDPE funnel-bottle } \\
\text { Collector }\end{array}$} \\
\hline $\begin{array}{l}\text { 6. Water Surface sampler } \\
\text { With open surface area } \\
\text { Continuously recirculated } \\
\text { Water }\end{array}$ & Dry Deposition & $\begin{array}{l}\text { Mediterranean } \\
\text { Climate area }\end{array}$ & - & Amodio et al. (2014) \\
\hline $\begin{array}{l}\text { 7. Polyethylene Sheets } \\
\text { And boxes (1-1.5m²) } \\
\text { And a brush }\end{array}$ & Airborne Particulate & $\begin{array}{l}\text { Xi'an, Shaanxi } \\
\text { China }\end{array}$ & - & Amodio et al. (2014) \\
\hline $\begin{array}{l}\text { 8. High Volume Air } \\
\text { Sampler. Flow rate of } \\
1.2 \mathrm{~m}^{3} / \mathrm{min}\end{array}$ & $\begin{array}{l}\text { Suspended Particulate } \\
\text { Matter }\end{array}$ & $\begin{array}{l}\text { Chawara in } \mathrm{K} \\
\text { South India }\end{array}$ & Kerala, & $\begin{array}{l}\text { Sarasamma and } \\
\text { Narayanan, } 2014\end{array}$ \\
\hline $\begin{array}{l}\text { 9. Direct gravitational } \\
\text { Deposition in to a filter }\end{array}$ & $\begin{array}{l}\text { Suspended Particulate } \\
\text { Matter }\end{array}$ & Uyo, Nigeric & Oct. 2012 - Mar 2013 & Moses and Orok, 2015 \\
\hline
\end{tabular}




\begin{tabular}{|c|c|c|c|c|}
\hline Paper & & & & \\
\hline $\begin{array}{l}\text { 10. High Volume Gravimetric } \\
\text { Sampler and the } 10 \mathrm{M} \\
\text { Multi fraction dust } \\
\text { Sampler }\end{array}$ & Particulate Matter & Benin, Nigeria & Nov. 2009 - Feb. 2010 & $\begin{array}{l}\text { Ediagbonya et al. } \\
\text { 13) }\end{array}$ \\
\hline $\begin{array}{l}\text { 11. Gravimetric High Volume } \\
\text { Air Sampler with Whatman } \\
\text { Cellulose filter paper }\end{array}$ & $\begin{array}{l}\text { Total Suspended } \\
\text { Particulate Matter }\end{array}$ & Calabar, Nigeria & 2 years & Ikamaise et al. (2013) \\
\hline $\begin{array}{l}\text { 12. Dichotomous Sampler } \\
\text { And Airmetrics } \\
\text { MiniVol Sampler }\end{array}$ & $\begin{array}{l}\text { Ambient Particulate } \\
\text { Matter }\end{array}$ & Vietnam & $\begin{array}{l}\text { Sept. } 2005 \text { - Jan. } 2006 \\
\text { April } 2010\end{array}$ & Co et al. (2014) \\
\hline $\begin{array}{l}\text { 13. Dual-Channel Sequential } \\
\text { Sampler Operating at a } \\
\text { Flow rate of } 2.3 \mathrm{~m}^{3} / \mathrm{h}\end{array}$ & $\begin{array}{l}\text { Desert Dust } \\
\mathrm{PM}_{10} \& \mathrm{PM}_{2.5}\end{array}$ & Tunis, Tunisia & 2008 & Kchih et al. (2015) \\
\hline
\end{tabular}




\section{Analytical Techniques used in PM studies}

Table 3 depicts the analytical techniques used in the determination of PM. The choice of instrumentation depends on the choice of researchers and availability.

Table 3: Analytical Techniques used in PM deposition studies

\begin{tabular}{|c|c|c|}
\hline & Analytical Technique & Determination \\
\hline 1. & $\begin{array}{l}\text { Gravimetric analysis, } \beta \text {-gauge } \\
\text { Monitoring }\end{array}$ & Particulate matter \\
\hline 2. & $\begin{array}{l}\text { X-Ray Fluorescence, } \\
\text { Proton - induced X-ray emission, } \\
\text { Instrumental Neutron Activated } \\
\text { Analysis Inductively Coupled } \\
\text { Plasma Spectroscopy, Emission } \\
\text { Spectroscopy, Atomic Absorption } \\
\text { Spectrophotometry. }\end{array}$ & $\begin{array}{l}\text { Elements (Na, Mg, Al, Si, P, S, } \\
\mathrm{Cl}, \mathrm{K}, \mathrm{Ca}, \mathrm{Ti}, \mathrm{V}, \mathrm{Cr}, \mathrm{Mn}, \mathrm{Fe}, \mathrm{Co}, \\
\mathrm{Ni}, \mathrm{Cu}, \mathrm{Zn}, \mathrm{Ga}, \mathrm{As}, \mathrm{Se}, \mathrm{Br}, \mathrm{Rb}, \\
\quad \mathrm{Sr}, \mathrm{Y}, \mathrm{Zr}, \mathrm{Mo}, \mathrm{Pd}, \mathrm{Ag}, \mathrm{Cd}, \mathrm{In}, \\
\mathrm{Sn}, \mathrm{Sb}, \mathrm{Ba}, \mathrm{La}, \mathrm{Au}, \mathrm{Hg}, \mathrm{Ti}, \\
\mathrm{Pb}, \mathrm{U}) .\end{array}$ \\
\hline 3. & Ion Chromatography & $\begin{array}{l}\text { Ions }\left(\mathrm{F}^{-}, \mathrm{Cl}^{-}, \mathrm{NO}_{2}^{-}, \mathrm{PO}_{4},{ }^{3-}, \mathrm{Br}^{-}, \mathrm{SO}_{4}^{2-}\right. \\
\left.\mathrm{NO}_{3}^{-}, \mathrm{K}^{+}, \mathrm{NH}_{4}^{+} \text {, and } \mathrm{Na}^{+}\right)\end{array}$ \\
\hline 4. & Automated Colorimetric analysis & $\left(\mathrm{Cl}^{-}, \mathrm{NO}_{2}{ }^{-}, \mathrm{SO}_{4}{ }^{2-}, \mathrm{NO}_{3}{ }^{-}, \mathrm{NH}_{4}{ }^{+}\right)$ \\
\hline 5. & Thermal Combustion method & Total carbon \\
\hline 6. & $\begin{array}{l}\text { Solvent Extraction method followed } \\
\text { by Gas Chromatography-mass } \\
\text { Spectroscopy. }\end{array}$ & Individual Organic Compounds \\
\hline 7. & $\begin{array}{l}\text { Thermal Manganese Oxidation } \\
\text { Method, Thermal Optical } \\
\text { Resistance or Thermal/Optical } \\
\text { Transmission method. }\end{array}$ & $\begin{array}{l}\text { Total Carbon, Elemental Carbon, } \\
\text { Organic Carbon, Carbonate Carbon. }\end{array}$ \\
\hline 8. & $\begin{array}{l}\text { Optical Absorption, Transmission } \\
\text { Densitometry, Integrating Plate } \\
\text { or Integrating Sphere method. }\end{array}$ & Absorb and (light absorbing Carbon). \\
\hline
\end{tabular}

Source: Guttikunda, (2009), Amodio et al. (2014)

As shown in Table 3 the various analytical methods used in PM studies are Thermal/Optical transmission method, Optical absorption method, Chromatography, Colorimetry, Gas chromatography, Gravimetric analysis, X-ray emission, Atomic absorption spectrophotometry, and Instrumental Neutron - activated analysis.

\section{Particulate Matter Results}

Table 4 depicts the results obtained from ambient samplings. It was observed that most of the results exceeded WHO limits.

Table 4. Particulate Matter Results obtained from different locations of the world

\begin{tabular}{llcc}
\hline S/N & LOCATION & \multicolumn{1}{c}{ PM } & REF \\
\hline 1. & $\begin{array}{l}\text { Post of Koper, } \\
\text { Slovenia }\end{array}$ & $>350 \mathrm{mg} / \mathrm{m}$ a day & Jereb et al. 2009 \\
2. & Taiwan & PM $2.5^{\left(25.76-60.99 \mu \mathrm{g} / \mathrm{m}^{3}\right)}$ & Tsai et al., 2011 \\
\hline
\end{tabular}




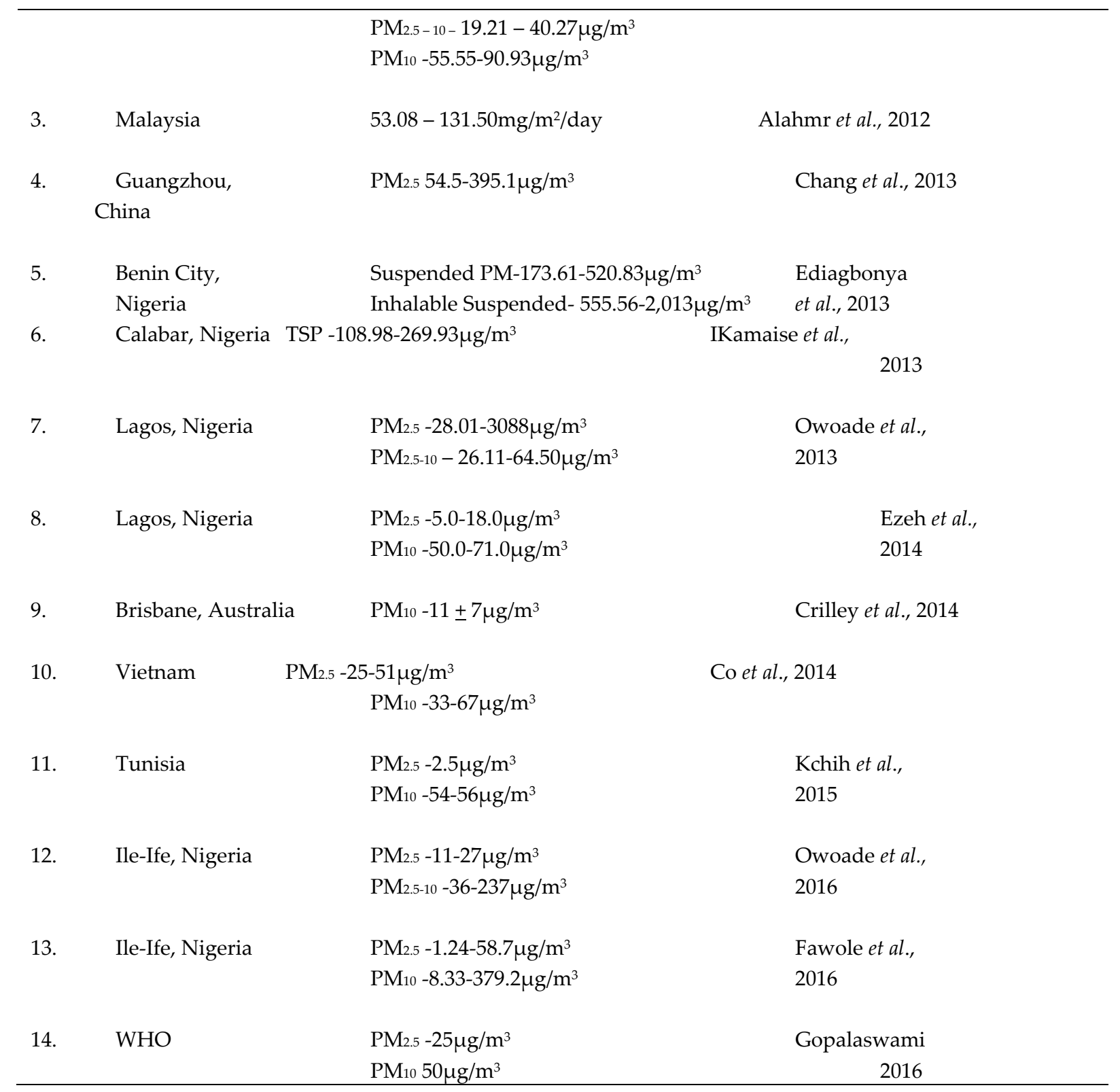

\section{PM and Source Apportionment}

Source Apportionments (SA) studies are conducted to identify and quantity the impact of different sources of air pollutants at receptor sites (Gulia et al., 2015). Based on the results obtained from evaluation, information can be gathered which will assist in the formulation and implementation of policies. SA studies are carried out using methods of analyses like chemical and morphological composition of pollutants. Chemical characterization is an important method in SA studies. It focuses on obtaining chemical parameters of the PM which depends on sources and their emission rates. To apportion the sources, receptor models are used, which quantify pollutant concentrations based on the ambient air pollutant data.

SA is an important tool for developing and developed countries. This has assisted the developed world to formulate policies which have assisted them to reduce the PM in their countries. The rate at which anthropogenic sources causes high PM had been reduced drastically. Efforts have been geared up by developing countries to reduce the rate of increase in PM. Countries like India, China, Nigeria and the rest have embarked upon similar studies and researches. 
There are many multivariate receptor models used in SA. Examples are Factor Analysis (FA), Principal Component Analysis (PCA), Eigenvector method, Positive Matrix Factors action (PMF), UNIMIX, Enrichment Factor (EF), Time Series Analysis, Multi-Linear engine (ME) analysis and species series analysis. PCA and FA are used to identify sources of PM, metals and can quantify estimation of the sources, identify dominant sources categories and the results obtained by Varimax rotated factor analysis for coarse and fine particles. PCA and FA assist in interpretation and assessment of the interrelations of the set of data under study.

Lastly, the correlation coefficient, factor loading and score obtained from FA are utilized to draw inferences about artificial and natural occurrence of the various trace elements (Roy and Singh, 2014). Fig 3 depicts the types of approaches to quantify PM sources.

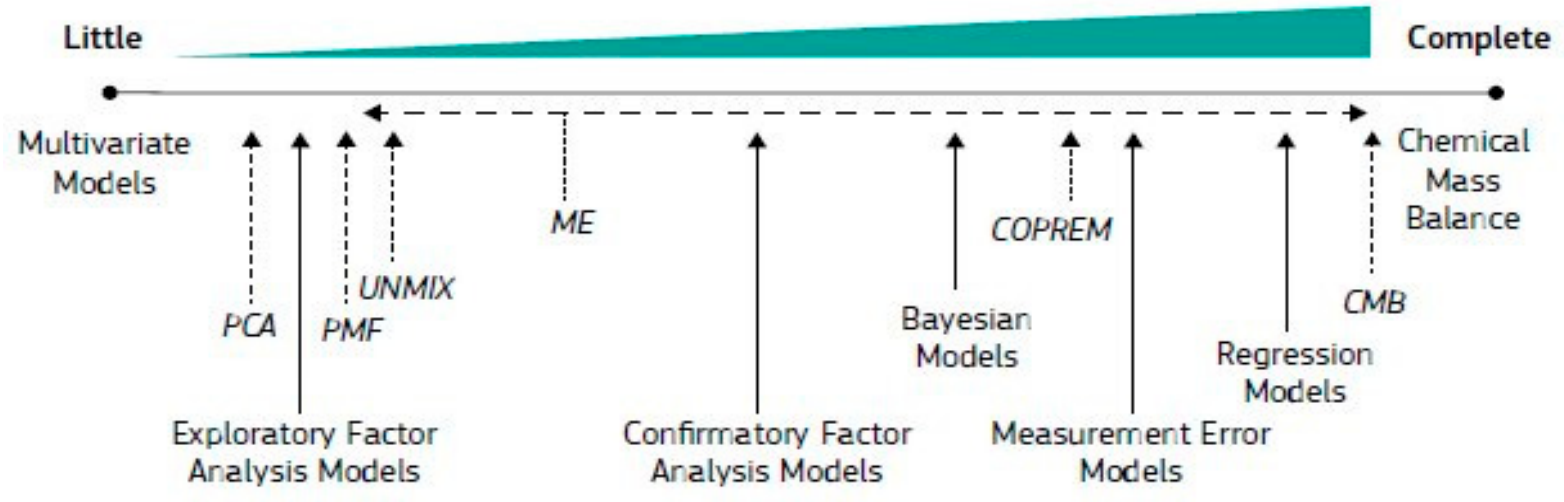

Fig 3: Types of Receptor Approaches to quantify PM sources Source: Johnson et al. (2011)

SA is synonymous to sources markers (source profiles). Elements are used to identify emission sources of pollutants. Table 5 shows the elements depicting the emission sources. The ratio between two metal concentrations represents the characteristics of a particular source which is an important input for receptor models.

Table 5. Maker Elements Depicting the Emission Sources

\begin{tabular}{|c|c|}
\hline Emission Source & Marker Elements* \\
\hline Soil & $\mathrm{Al}, \mathrm{Si}, \mathrm{Sc}, \mathrm{Ti}, \mathrm{Fe}, \mathrm{Sm}, \mathrm{Ca}$ \\
\hline Road dust & $\mathrm{Ca}, \mathrm{Al}, \mathrm{Sc}, \mathrm{Si}, \mathrm{Ti}, \mathrm{Fe}, \mathrm{Sm}$ \\
\hline Sea salt & $\mathrm{Na}, \mathrm{Cl}, \mathrm{Na}^{+}, \mathrm{Cl}^{-}, \mathrm{Br}, \mathrm{l}, \mathrm{Mg}, \mathrm{Mg}^{2+}$ \\
\hline Oil burning & $\mathrm{V}, \mathrm{Ni}, \mathrm{Mn}, \mathrm{Fe}, \mathrm{Cr}, \mathrm{As}, \mathrm{S}, \mathrm{SO}_{4}{ }^{2-}$ \\
\hline Coal burning & $\mathrm{Al}, \mathrm{Sc}, \mathrm{Se}, \mathrm{Co}, \mathrm{As}, \mathrm{Ti}, \mathrm{Th}, \mathrm{S}$ \\
\hline Iron and steel industries & $\mathrm{Mn}, \mathrm{Cr}, \mathrm{Fe}, \mathrm{Zn}, \mathrm{W}, \mathrm{Rb}$ \\
\hline Non-ferrous metal industries & $\mathrm{Zn}, \mathrm{Cu}, \mathrm{As}, \mathrm{Sb}, \mathrm{Pb}, \mathrm{Al}$ \\
\hline Glass industry & $\mathrm{Sb}, \mathrm{As}, \mathrm{Pb}$ \\
\hline Cement industry & $\mathrm{Ca}$ \\
\hline Refuse incineration & $\mathrm{K}, \mathrm{Zn}, \mathrm{Pb}, \mathrm{Sb}$ \\
\hline Biomass burning & $\mathrm{K}, \mathrm{C}_{\text {ele }^{\prime}} \mathrm{C}_{\text {org' }}, \mathrm{Br}, \mathrm{Zn}$ \\
\hline Automobile gasoline & $\mathrm{C}_{\mathrm{ele}^{\prime}} \mathrm{Br}, \mathrm{Ce}, \mathrm{La}, \mathrm{Pt}, \mathrm{SO}_{4}{ }^{2-}, \mathrm{NO}_{3}^{-}$ \\
\hline Automobile diesel & $\mathrm{C}_{\mathrm{org}^{\prime}} \mathrm{C}_{\text {ele }^{\prime}}, \mathrm{S}, \mathrm{SO}_{4}{ }^{2-}, \mathrm{NO}_{3}^{-}$ \\
\hline Secondary aerosols & $\mathrm{SO}_{4}^{2-}, \mathrm{NO}_{3}^{-}, \mathrm{NH}_{4}^{+}$ \\
\hline
\end{tabular}

Source: Johnson et al. (2011) 


\section{CONCLUSION}

It can be concluded that PM is a global problem. Developing countries too like the developed ones should see this as a joint task to tackle and so collaborative efforts should be put in place with stakeholders throughout the world. The knowledge of PM and AQI is important

\section{REFERENCES}

Abiye O.E., Obioh I. B and Ezeh G. C. (2013). Elemental characterization of urban particulates at receptor locations in Abuja, North Central Nigeria. ATM. Env. 81: 695.701.

Alahmr F.O, Othman M, Wahid N.B.A, Halim A. A. and Latif M. T (2012). Composition of dust fall around semi-urban areas of Malaysia. Aerosol and Air Quality Res. 12:629 -642.

Amodio M, Catino S, Dambruoso P.R, Gennaro G.De, Gilio A. Di, Giunngato P, Laiola E, MarzoccaA, Mazzone A, Sardaro A and Tutino M (2014). Atmospheric deposition: Sampling procedures, analytical methods, and main recent findings from the scientific literature. Adv. Meteorology. http://dx.doi.org/10.1155/2014/161730.

Azimi S, Luduig A, Thevenot Daniel R and Colin J.L (2003). Trace metal determination in total atmospheric deposition in rural and urban areas. The Sci. of the Total Environ. 308: 247- 256.

Belis C. A, Larsen B.R, Amato F, Haddad I.E, Favez O, Harrison R.M, Hopke, P.K, Nava S, Paatero P, Prevot A, Quass U, Vecchi R and Viana M (2014). European guide on air pollution source apportionment with receptor models. Joint Research Centre (JRC) Reference Reports.

Chang S.Y, Chou C.C.K, Liu S, and Zhang Y. (2013). The characteristics of PM2.5 and its chemical compositions between different prevailing wind patterns in Guangzhou. Aerosol and Air Quality Res. 13:1373-1383.

Co H.X, Dung N.T, Oanh N.T.K, Hang N.T, Phuc N H and Le H.A (2014). Levels and Composition of ambient particulate matter at a mountainous rural site in Northern Vietnam. Aerosol and Air Quality Res. 14:1917-1928.

Crilley L.R, Ayoko G.A, Stelcer E, Cohen D.D, Mazaheri M and Morawska L (2014). Elemental composition of ambient fine particles in urban schools: sources of children's exposure. Aerosol and Air Quality Res. 14:1906-1916.

Dallman I.R, Onasch T.B, Kirchstetter T.W, Worton D.R, Fotner E.C, Herndon S.C, Wood E.C, Franklin J.P, Worsnop D.R, Goldstem A.H and Harley R.A (2014). Characterization of particulate matter emissions from on-road gasoline and diesel vehicles using a foot particle aerosol mass spectrometer. Atm.Chem. Phys. 14:7585-7599.

Department for Environmental Food \& Rural Affairs (2015). Policy Paper 2010 to 2015 government policy: Environmental Quality. GOV. UK

Edesess M (2011). Roadside air pollution in Hong Kong: why is it still so bad? School of Energy and Environment, City University of Hong Kong. 19 pages

EEA (European Environment Agency) (2014). http://acm.eionet.europa.eu. Accessed in January, 2014. Ezeh G.C, Obioh I.B, Asubiojo O.I and Abiye O.E (2012). PIXE Characterization of PM10 and PM2.5 particulates sizes collected in Ikoyi Lagos, Nigeria. Toxicol. \& Environ. Chem. 94(5): 884894.Dol:10.1080/02772248.2012.674133. 
Ezeh G.C, Obioh I.B, O. I Asubiojo, Chiari M, Nava S, Calzolai G, Lucarelli F and Nuviademu C. K (2014). Elemental Compositions of PM10-2.5 and PM2.5 aerosols of a Nigerian Urban City using ion beam analytical techniques. Nucl. Inst. E Methods in Phy. Res. B. 334: 28-33.

Fawole O.G, Olofinjana B and Owoade O.K (2016). Compositional and air-mass trajectory analysis of a heavy dust episode (HDE) aerosols in Ile-Ife, Nigeria. British J. Appl. Sci E Tech. 13(1): 1-15.

Gopalaswami R. (2016). A study on effects of weather, vehicular traffic and other sources of particulate air pollution on the city of Delhi for the year 2015. J. Env. Poll. E Human Health. 4(2) 24. 41.

Gulia S, Shiva Nagendra Sm, Khare M and Khanna I (2015). Urban air quality management - A review. Atm. Poll. Res. 6:286-304.

Guttikunda S.K. and Gurjar B.R (2012). Role of meteorology in Seasonality of air pollution in megacity Delhi, India. Environ. Monit. Assess. 184:3199-3211. Dol:10.1007/S10661-011-2182-8.

Ikamaise V.C., Akpan I.O., Essiett A.A. and Uwah I.E (2013). Concentrations and source apportionment of total suspended particulate matter in Calabar Air basin. Int. J. Dev. E Sust. 2 (2) 1203-1213.

Jereb G, Marzi B, Cepak F, Katz S. A and Polj AK B (2009). Collection and analysis of particulate matter deposition around the Port of Koper. Int. J. Sanitary Eng. Res. 3(1): 1-15.

Johnson T.M, Guttikunda S, Wells G. J, Artaxo P, Bond T.C, Russell A. G, Watson J.C and West J (2011). Tools for improving air quality management. A review of Top-down source apportionment techniques and their application in developing countries. ESMAP Formal report 339/11.

Kchih H, Perrino C and Cherif S. (2015). Investigation of desert dust contribution to source apportionment of PM10 and PM2.5 from a Southern Mediterranean coast. Aerosol and Air Quality Res. 15:454-464.

Langner M, Draheim T, and Endlicher W (2011). Particulate matter in the urban atmosphere: Concentration, distribution reduction - results of studies in the Berlin metropolitan area in perspective in urban ecology, ecosystems and interactions between humans and nature in the metropolis of Berlin, W. Endlicher, Ed., Pp. 15-41, Springer, Berlin, Germany.

Minka N.S and Ayo J.O (2014). Influence of Cold - dry (harmattan) season on colonic temperature and the development of pulmonary hypertension in broiler chickens, and the modulating effect of ascorbic acid. Open Access Animal Physiology 6.

Moses E.A and Orok U.B. (2015). Contamination and health risk assessment of suspended particulate matter (SPM) in Uyo, Niger Delta, Nigeria. J. Sci. Res. P Reports 6 (4): 276-286.

National Environmental Standards and Regulations Enforcement Agency - NESREA (2016). Mandate of the Agency. Retrieved: http://www.nesrea.gov.ng/about/index.php.

Onabowale M.K. and Owoade O.K (2015). Assessment residential indoor outdoor airborne particulate matter in Ibadan, Southwestern Nigeria. Donnish J. Physical. Sci 1(1):001 - 007.

Ontario Ministry of the Environment and Climate Change (2010). Fine particulate matter. 
Orogade S.A, Owoade K.O, Hopke P.K, Adie D.B, Ismail A and Okuofu C.A (2016). Source apportionment of fine and coarse particulate matter in industrial areas of Kaduna, Northern, Nigeria. Aerosol and Air Quality Res. 16:1179-1190.

Owoade O.K, Fawole O.G, Olize F.S, Ogundele L.T, Olaniyi H.B, Almeida Marta S, HOM and Hopke P.K (2013) Characterization and Source Identification of airborne particulate loadings at receptor site Classes of Lagos mega city, Nigeria. J. Air \& Waste Mgt. Ass. 63(:9): 1026 -1035 Dol:10.1080/10962247.2013.793627.

Owoade K.O, Hopke P.K, Olise F.S, Ogundele L.Y, Fawole O.G, Olaniyi B.H, Jegede O.O, Ayoola M. A and Bashiru (2015). Chemical Compositions and Source identification of particulate matter (PM2.5 and PM2.5-10) from a scrap iron and steel smelting industry along the Ife-Ibadan highway, Nigeria. Atm. Poll. Res. 6. $107-119$.

Roy D and Singh G (2014). Source Apportionment of Particulate Matter (PM10) in an integrated coal mining complex of Jharia Coalfield, Eastern India, A review. Int. Journal of Engineering Research and Applications. 4: 4 (Version 1): 97-113.

Sarasamma J.D and Narayanan B. K (2014). Air quality assessment in the surrounding of KMML Industrial Area, Chavara in Kerala, South India. Aerosol and Air Quality Res. 14:179-1778.

Taiwo A.M, Arowolo T. A, Abdulahi K. L and Taiwo O.T (2015). Proceedings of the $14^{\text {th }}$ Int. Conf. on Env. Sci \& Tech Rhodes, Greece, 3-5 Sept.

Tasic M, Mijic Z, Rajsic S, Stjic A, Radenkonic M and Joksic J (2009). Source apportionment of Atmosphere bulk deposition in the Belgrade urban area using positive matrix factorization $2^{\text {nd }}$ Int. Workshop on Non-equilibrium processes in plasmas and Environ. Sci. IOP Publishing. J. of Phy: Conference Series 162. 012018. Doi:10.1088/1742-6596/162/1/012018.

Tsai H, Yuan C, Hung C and Lin C (2011). Physiochemical properties of PM2.5 and PM2.5-10 at inland and offshore sites over southeastern coastal region of Taiwan Strait. Aerosol and Air Quality Res. 11:664678.

USEPA (US Environmental Protection Agency) (2012). Our nation's air status and trends through 2010, EPA-454/ R-12-001, 32pages.

WHO (2014). 7 million premature deaths annually linked to air pollution. http://www.who.int/media centre/news/releases/2014/air-pollution/en/.

(C) 2016 by the authors; licensee Preprints, Basel, Switzerland. This article is an open access article distributed under the terms and conditions of the Creative Commons by Attribution (CC-BY) license (http://creativecommons.org/licenses/by/4.0/). 